Article

\title{
Impact of Window to Wall Ratio on Energy Loads in Hot Regions: A Study of Building Energy Performance
}

\author{
Mamdooh Alwetaishi ${ }^{1, *(D)}$ and Omrane Benjeddou ${ }^{2,3}$ \\ 1 Department of Civil Engineering, College of Engineering, Taif University, P.O. BOX 11099, \\ Taif 21944, Saudi Arabia \\ 2 Prince Sattam bin Abdulaziz University, College of Engineering, Department of Civil Engineering, \\ Alkharj 16273, Saudi Arabia; o.benjeddou@psau.edu.sa \\ 3 University of Tunis El Manar, National Engineering School of Tunis, Civil Engineering Laboratory, BP 37, \\ Tunis-Belvédère 1002, Tunisia \\ * Correspondence: m.alwetaishi@tu.edu.sa
}

Citation: Alwetaishi, M.; Benjeddou, O. Impact of Window to Wall Ratio on Energy Loads in Hot Regions: A Study of Building Energy Performance. Energies 2021, 14, 1080. https:// doi.org/10.3390/en14041080

Academic Editor:

Giovanni Pernigotto

Received: 23 November 2020

Accepted: 15 February 2021

Published: 18 February 2021

Publisher's Note: MDPI stays neutral with regard to jurisdictional claims in published maps and institutional affiliations.

Copyright: (c) 2021 by the authors. Licensee MDPI, Basel, Switzerland. This article is an open access article distributed under the terms and conditions of the Creative Commons Attribution (CC BY) license (https:// creativecommons.org/licenses/by/ $4.0 /)$.

\begin{abstract}
The concern regarding local responsive building design has gained more attention globally as of late. This is due to the issue of the rapid increase in energy consumption in buildings for the purpose of heating and cooling. This has become a crucial issue in educational buildings and especially in schools. The major issue in school buildings in Saudi Arabia is that they are a form of prototype school building design (PSBD). As a result, if there is any concern in the design stage and in relation to the selection of building materials, this will spread throughout the region. In addition to that, the design is repeated regardless of the climate variation within the kingdom of Saudi Arabia. This research will focus on the influence of the window to wall ratio on the energy load in various orientations and different climatic regions. The research will use the energy computer tool TAS Environmental Design Solution Limited (EDSL) to calculate the energy load as well as solar gain. During the visit to the sample schools, a globe thermometer will be used to monitor the globe temperature in the classrooms. This research introduces a framework to assist architects and engineers in selecting the proper window to wall ratio (WWR) in each direction within the same building based on adequate natural light with a minimum reliance on energy load. For ultimate WWR for energy performance and daylight, the WWR should range from $20 \%$ to $30 \%$, depending on orientation, in order to provide the optimal daylight factor combined with building energy efficiency. This ratio can be slightly greater in higher altitude locations.
\end{abstract}

Keywords: energy consumption; window to wall ratio; glazing; solar gain; daylight

\section{Introduction}

Buildings in different types and forms are responsible for about $40 \%$ of the energy demand, which is considerable amount [1]. In reference to the concept of green architecture, windows are considered to be the weakest component of the building envelope in terms of performance and energy efficiency [2-4]. They are responsible for the largest amounts of heat transmittance, direct solar gain, and thermal bridging in buildings [5]. Depending on the outdoor conditions and glazing size, windows are responsible for around $10 \%$ to $25 \%$ of the total heat loss [6]. Therefore, adjusting the window to wall ratio (WWR) can lead to a considerable impact on energy compared with adjusting the external walls' thickness [3,7]. In addition to the size of the window, its orientation has a relatively great influence on energy consumption and the internal thermal conditions [8]. It is noteworthy that all glazing systems, regardless of the façade orientation, should be minimized in hot regions [9]. Considering this, the glazing systems should be carefully designed, especially in regions where the level of solar radiation is considerably high. This paper aims to investigate the influence of WWR on energy load under two different microclimatic regions in Saudi Arabia, namely hot and dry and high land regions. This research investigates 
the widely spread WWR ratios in the region based on the work of Alwetaishi [4], who observed a varied WWR of $5 \%, 10 \%, 20 \%, 30 \%$, and $40 \%$ on the external wall. Similarly, a work carried out in a similar climate showed that $40 \%$ of WWR is optimum when it comes to controlling the energy and environmental performance [10]. In contrast, in other climatic zones such as in the case of Changzhou in China, a study conducted by Li [11] highlighted that if the WWR exceeds $60 \%$ in hot months, then the indoor thermal condition would suffer. This shows that WWR is strongly subjected to the local climate condition (Figures 1 and 2). Even in a cold climate, the use of glazing has to be controlled to avoid overheating in the summer months. In winter, passive solar gain is crucial to increasing the heat gain with a higher g-value [12].

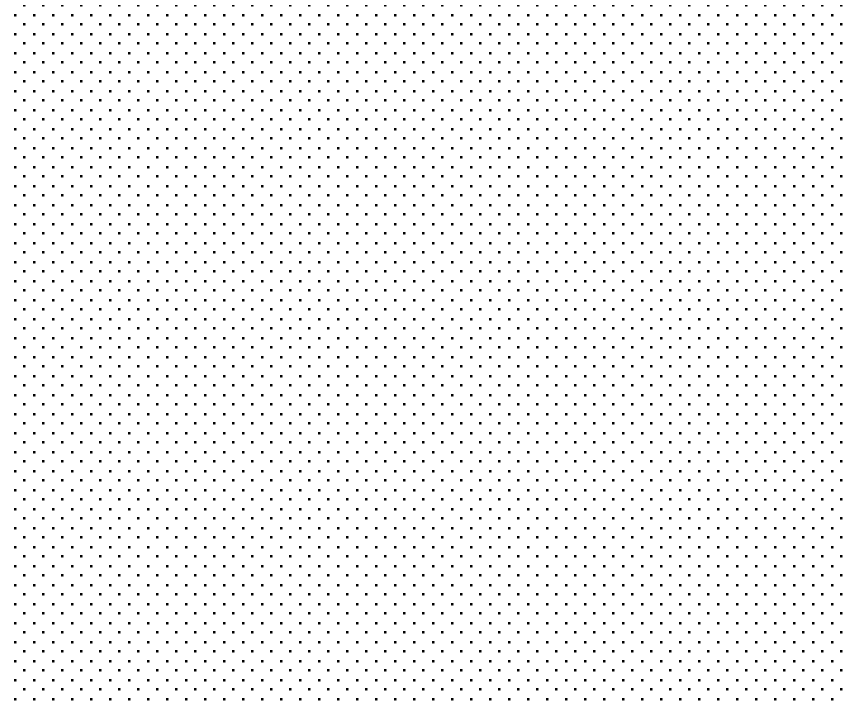

Figure 1. Topographic map of Saudi Arabia showing the location and elevation of Riyadh and Abha [13].

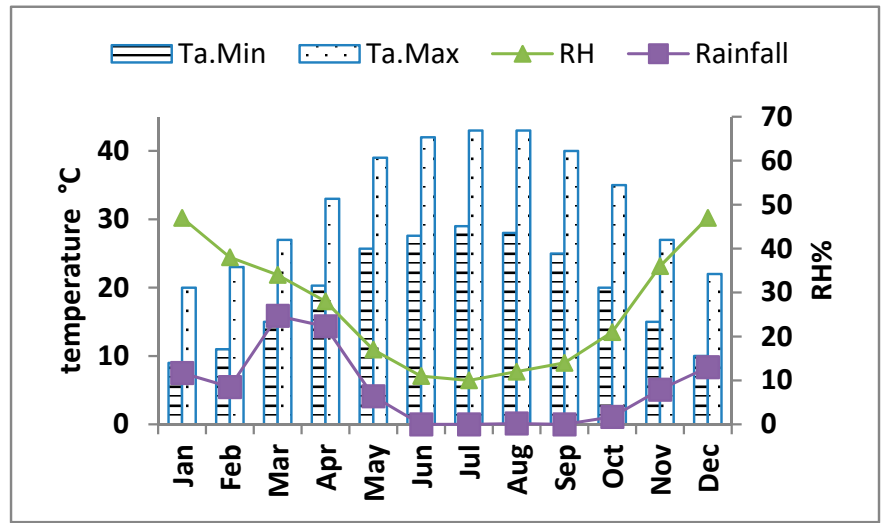

(a)

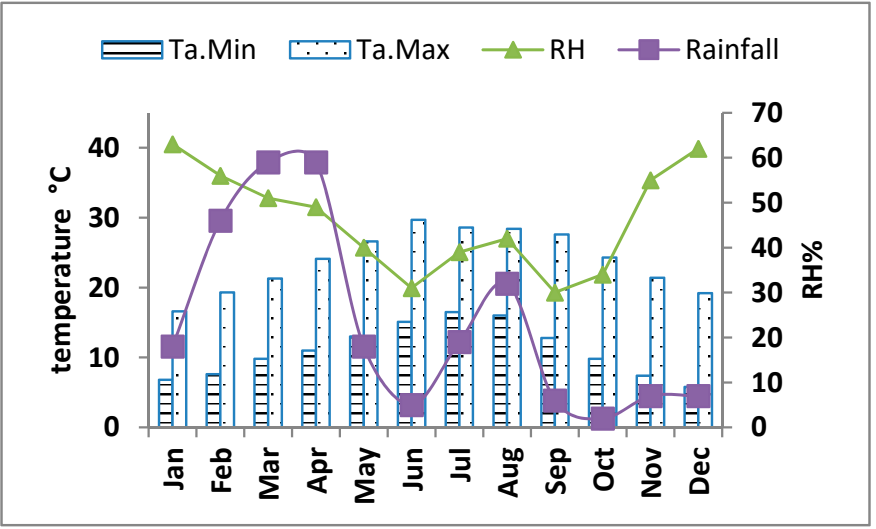

(b)

Figure 2. Climatic condition of: (a) Riyadh city and (b) Abha city.

The study and configuration of WWR should be included in the design stage to improve the energy performance of the building [1]. However, there are other parameters that need to be highlighted that affect energy building performance such as the glazing type and use of shading. In a study conducted by Cesari and Khoukhi [14,15], the results indicated that retrofitting may have a major influence on the building's energy pattern as well as the cost of the energy consumption. It has to be mentioned that orientation is linked to WWR. It controls the amount of solar gain that the building envelope is exposed to [16]. 


\section{Importance and Novelty of This Research}

This research will contribute to providing a framework on the optimum window to wall ratio (WWR) to be used by architects in the early design stage in hot regions by considering different orientations with a connection to energy consumption. This is crucial in hot regions. In addition to that, the recommendation on WWR in various climatic regions can also be used in existing buildings. Most publications focus on either energy performance or daylight. However, this study links the two variables as they aid the creation of a framework on the ultimate WWR in buildings. Each direction in the building should have its own WWR based on energy consumption as well as the daylight factor. This will improve the indoor environmental quality and also improve the energy performance of the buildings. Figure 3 represent the flow chart of the research of this study.

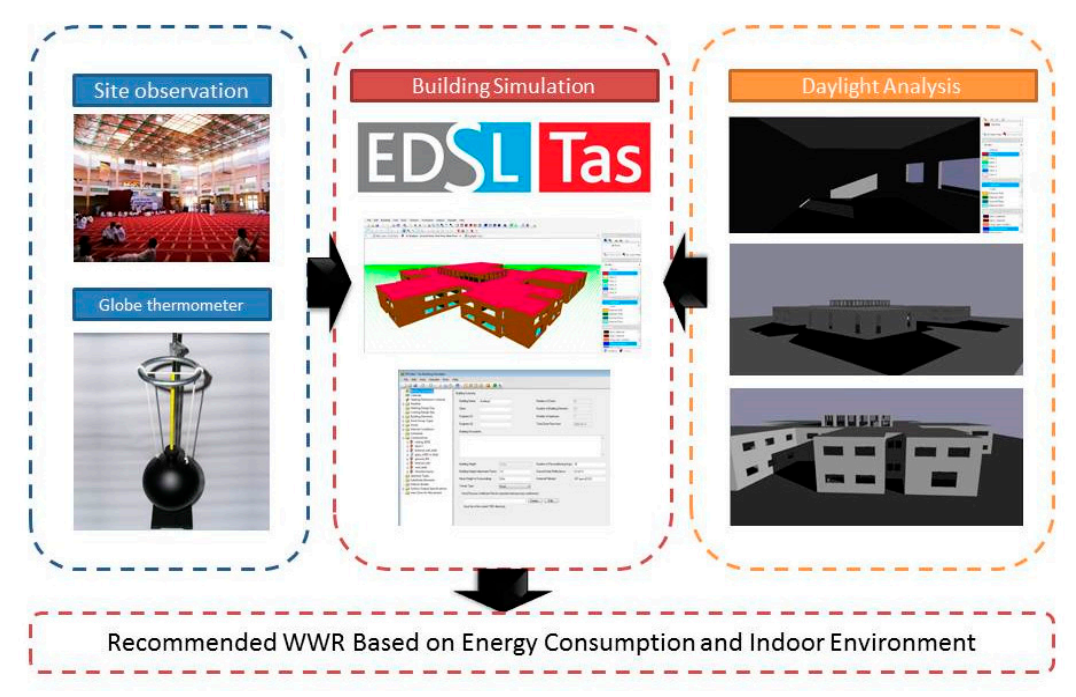

Figure 3. Diagram of the research methodology.

\section{Method and Study Design}

The investigated case study in this research is one of the modern high school designs in Saudi Arabia, as presented in Figure 3. This school was previously investigated as it is one of the prototype designs in Saudi Arabia [4]. This study investigated the building envelope of the schools in different climatic zones in Saudi Arabia, specifically hot and dry, hot and humid, and a higher mountain altitude, while taking into consideration variables such as glazing type, building material construction, and air conditioning systems in the schools. The schools investigated were in two climatic zones within Saudi Arabia, specifically in the cities of Riyadh and Abha. The different WWRs were evaluated using the TAS EDSL modelling program $(10 \%$ and $40 \%)$, which is one of the most advanced and widely used software in the simulation of energy and sustainable buildings. Energy load, solar gain, and indoor air temperature were obtained from TAS based on weather data to support the case studies. Figure 3 details the flow chart that was part of the methodology.

\subsection{Case Study—Building Design}

The case study is a prototype school building design (PSBD). All public schools in Saudi Arabia come in the form of a PSBD. The same design is used in all regions of the country regardless of the diversity of the local climate (Figure 1). This shows the importance of this study, as building design becomes more important when it is used multiple times. The building consists of two storeys. In this study, three classrooms were selected, each one facing a different orientation to investigate the significance of orientation. The schools were visited in summer 2018 for one week. 


\subsection{Study Simulation}

In the cities of Riyadh (hot and dry) and Abha (high altitude), the indoor temperature and relative humidity were both analyzed. In addition, different types of glazing were investigated due to its impact in hot regions. The research team, during their visit, noticed that the schools used only single glazing, which is not acceptable in such a climate. As a result, the current study highlights the significance of this decision. It is easy to modify this as part of retrofitting school buildings. The construction of the school and its characteristics have been presented in Table 1 . In terms of the thermostat set points, they were $19{ }^{\circ} \mathrm{C}$ and $25^{\circ} \mathrm{C}$ for heating and cooling, respectively. The selection of a thermostat was based on the acceptable thermal comfort level in the country [17]. The study also used a parametric study of different WWRs ranging from $10 \%$ to $40 \%$. This range is determined based on the acceptable window to wall ratio in hot regions. The analysis was focused on energy consumption, indoor air temperature and relative humidity, and daylight analysis.

Table 1. Characteristics of the existing school building evaluated by TAS EDSL.

\begin{tabular}{|c|c|c|c|c|c|c|}
\hline & Layers & Width (mm) & & Conductivity (V & (mK) & $\begin{array}{c}\text { Total U } \\
\text { Value } \\
\left(\mathrm{W} / \mathrm{m}^{2} \cdot{ }^{\circ} \mathrm{C}\right)\end{array}$ \\
\hline \multirow{3}{*}{ External Wall } & Block & 100 & & 0.85 & & \multirow{3}{*}{0.43} \\
\hline & Insulation & 90 & & 0.048 & & \\
\hline & Block & 100 & & 0.85 & & \\
\hline Internal Wall & Block & 100 & & 175 & & 4.4 \\
\hline \multirow{4}{*}{ Ground } & Concrete screed & 50.0 & & 1.28 & & \multirow{4}{*}{0.316} \\
\hline & Concrete & 125.0 & & 0.87 & & \\
\hline & $\begin{array}{l}\text { Crashed brick } \\
\text { aggregate }\end{array}$ & 75.0 & & 0.55 & & \\
\hline & Sand dry & 1000.0 & & 0.32 & & \\
\hline \multirow{3}{*}{ Roof } & Concrete & 100 & & 0.3 & & \multirow{3}{*}{0.274} \\
\hline & Roofing Felt & 5.0 & & 0.41 & & \\
\hline & Slate Grey & 10.0 & & 2.0 & & \\
\hline \multicolumn{7}{|c|}{ Glazing type } \\
\hline \multirow[t]{2}{*}{ Glazing } & $\begin{array}{l}\text { Type of } \\
\text { Glazing }\end{array}$ & $\begin{array}{c}\text { Solar } \\
\text { Reflectance }\end{array}$ & $\begin{array}{c}\text { Solar } \\
\text { Absorptance }\end{array}$ & $\begin{array}{c}\text { Solar } \\
\text { Transmittance }\end{array}$ & Emissivity & $\begin{array}{c}\text { Total U } \\
\text { Value } \\
\left(\mathbf{W} / \mathbf{m}^{2} \mathbf{K}\right)\end{array}$ \\
\hline & Single & 0.070 & 0.115 & 0.7 & 0.845 & 5.53 \\
\hline
\end{tabular}

\subsection{The Use of a Globe Thermometer}

This study used a globe thermometer during the site visits. The aim of this investigation was to support the findings of the study simulation and to provide a detailed monitoring of the current design of the selected classrooms in the schools (Figure 3). The study used a one-meter grid to place the globe thermometer in order to monitor the impact of glazing size and distance on the globe temperature. This study expected to highlight the impact of solar and outdoor temperature on the indoor climatic condition.

\subsection{Validation and Calibration}

TAS EDSL is used globally to conduct energy simulations. It has been used in abundant publications such as $[4,18-23]$ the studies conducted in Saudi Arabia, Singapore, Austria, Italy, Chile, Poland, and the United Kingdom, respectively. In addition, the software has been validated and calibrated by Alwetaishi several times previously [24,25]. The same prototype, located in Taif city, has been monitored using a data-logger tool to compare 
the results to the results that were simulated. The internal condition of the software was modified to accommodate the different building types in order to provide accurate results. The major issue was the adjustment of the ventilation and the infiltration of heat loss and gain within the model. Two different operations were validated using the operations of the air conditioning mode and the free running mode (Figure 4), where Figure 5 represent the case study model of school building.

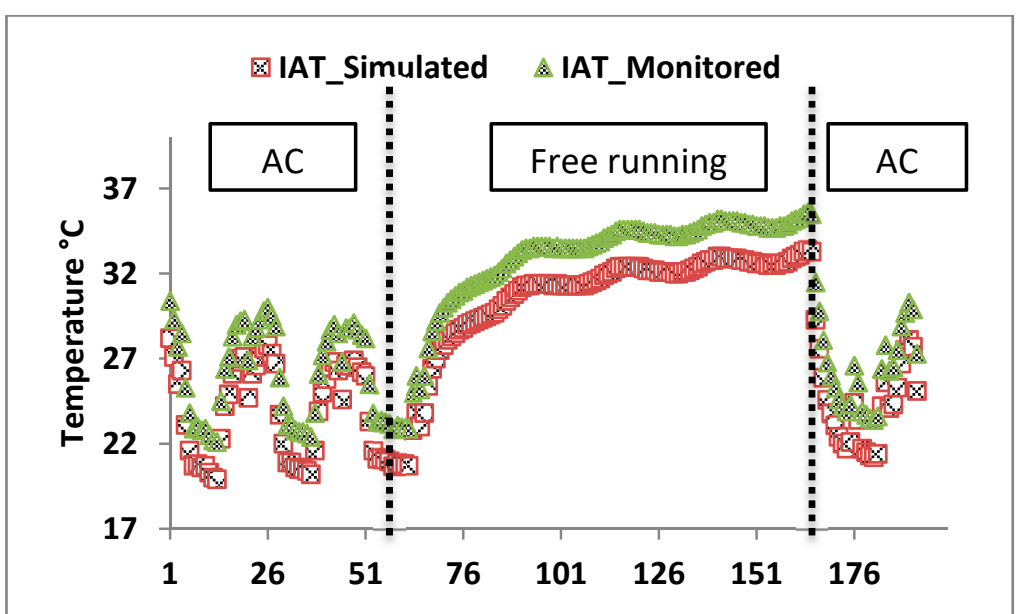

Figure 4. Software validation using the data-logger.

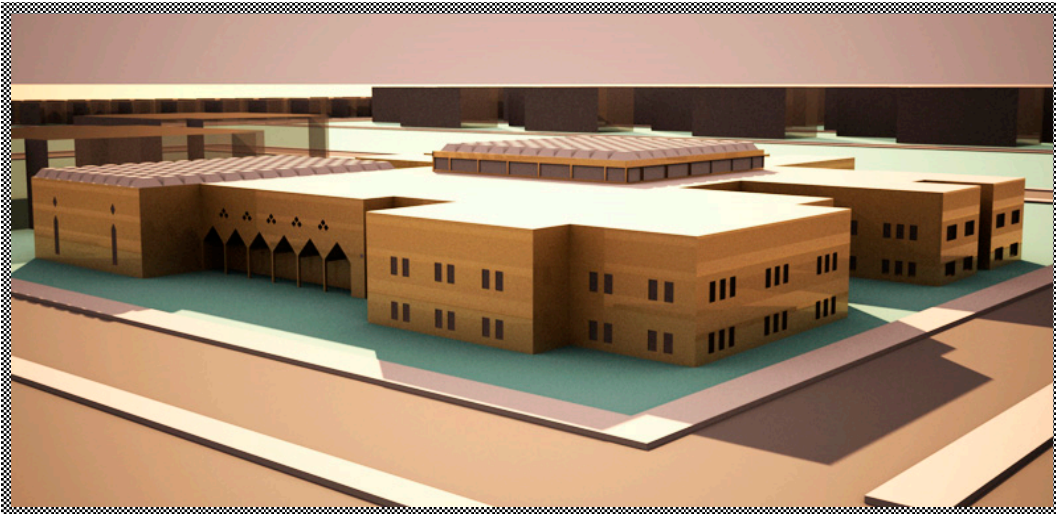

(a)

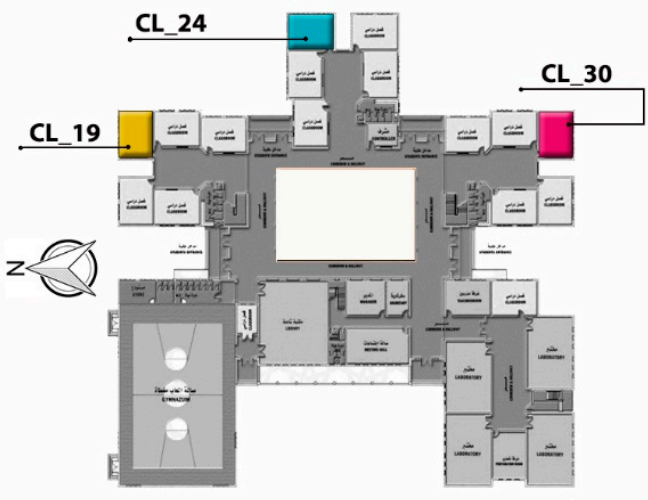

(b)

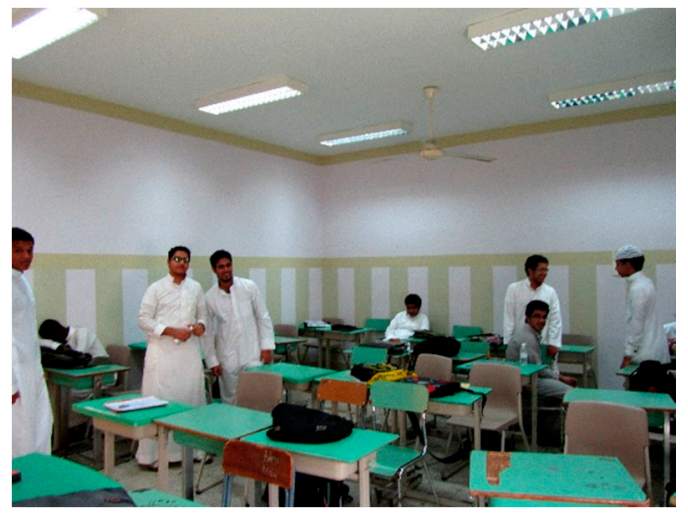

(c)

Figure 5. School building where: (a) is a 3D simulated view of school, (b) is a plan showing the tested classrooms, and (c) is the internal view of one of the tested classrooms. 


\section{Results and Discussion}

Even though Saudi Arabia is considered to be an extremely hot region, there is a diverse climatic condition across the country (Figure 1). The difference between the two cities studied is enormous, which should be reflected in the building design. Regarding the heating and cooling load in the city of Abha, there were a clear heating load in winter (Figure 6). This is due to the outdoor air temperature, which averages about $15{ }^{\circ} \mathrm{C}$. It was noted that each orientation was impacted differently. For instance, the north-facing classroom showed nearly no difference between $10 \%$ and $40 \%$ WWR due to the absence of direct solar radiation. In contrast, the south-facing classroom was affected dramatically to the extent that in the case of $40 \%$ WWR, there was no heating load at all. This indicates the importance of considering the diversity of the WWR in each orientation within the same building. The heat load patterns in spring, summer, and autumn between $10 \%$ and $40 \%$ WWR were similar, as the position of the sun is also similar. The previous studies proved that in passive solar design, winter is always the first approach to consider. The north-facing zone had the worst scenario while the south-facing had the best scenario, with a zero-heating load at some times of the day and night. This shows that it is important to consider not only the location of the city but also the orientation of each zone within the same building. These findings support the view of [7]. Alwetaishi studied the influence of various orientations on the indoor temperature in Taif city, which has a similar climate to Abha. For winter passive heating, north-facing zones are not as effective as east and west-facing zones where the sun's position allows for direct solar heat gain to take place, and thus the number of north-facing zones should be minimized compared to the other zones. In addition, in summertime, a large glazing area in highland places such as Abha is important to allow for natural ventilation as in summer with a $40 \%$ WWR there is no cooling load at all. Based on the discussed findings and upon observing the maximum values of solar heat gain, the WWR for each direction in highland places such as Abha can be stated as follows: $40 \%, 35 \%$, and $35 \%$ in the north, east, and south respectively. This is quite compatible with the findings of the optimum WWR in the city of Taif, which has a similar climate to Abha [7]. Generally, a larger WWR is more acceptable in Abha in winter in terms of a better level of performance. The $40 \%$ WWR has resulted in a very low heating load compared to $10 \%$. In addition to that, there is a clear variation in orientations. The south orientation was found to be the easiest facing zone with which to achieve a zero-heating load in winter in comparison with the east and north. In spring, as the outdoor temperature starts to soar, a clear cooling load takes place with no heating load. Due to the direct access to sunlight, the east orientation has the largest cooling load. As a result, the WWR of this classroom has to be precisely designed due to the large amount of cooling in the spring and the low heating in winter. Regarding the energy loads in the city of Riyadh, which is considered to be a hot and arid climate, there is a large cooling load in summer and an adequate heating load in winter. This is due to the harsh outdoor climate which was monitored in two classrooms in the two cities using a globe thermometer. The optimization of the best WWR in such a climate is crucial because of its reverse relationship between summer and winter. It is better for windows to be smaller in summer yet larger in winter to allow for passive solar heating. For instance, it can be noted that southern facing zones have a larger zero heating load in the case of $40 \%$ WWR compared to $10 \%$. However, the latter scenario has a larger cooling load compared to the $10 \% \mathrm{WWR}$. It is suggested that the maximum size of the WWR in hot and dry places should not overtake $30 \%$ in north-facing zones and $25 \%$ in both east and south-facing zones.

As far as the influence of WWR on the energy loads is concerned, based on the results presented in Figure 6, there is a general decrease in the heating load in the city of Abha when the WWR gets larger, while there is a clear increase when there is a larger WWR in summer. This varies based on orientation. For instance, the largest drop was found to be in the southern facing classroom CR30, where there was a 9\% decrease in energy load while the lowest drop was found to be in the north classroom at only $2 \%$. In contrast, in the city of Riyadh there was a different impact of WWR on energy consumption, as can be seen in 
Figure 6. In winter, the influence of the modified WWR was found to be minor, except for in the southern facing classroom where there was a 30\% drop in heating load, which allows passive solar heating in winter. This is due to the exposure to direct solar radiation of the south external walls and glazing system. On the other hand, there was a slight impact due to the WWR on the energy load in summer, where there was an approximately $10 \%$ increase in the cooling load in all directions. As a result, the modification of WWR is crucial in southern facing zones. In addition, the WWR is an effective passive approach for heating buildings located in areas with a cold winter. This finding supports the work of Detsi [12], which indicates the importance of enhancing the passive heating design in cold regions. Figure 7 shows the impact of solar radiation in different climatic conditions.

$10 \%$, WWR

\section{Heating and Cooling of Abha City}

Winter
*CL.C19.10\% - - CL.C24.10\% - CL.C30.10\% - - HL.C19.10\%

$=-\mathrm{HL} . \mathrm{C} 24.10 \%+\mathrm{HL} . \mathrm{C} 30.10 \%-\mathrm{W} . \mathrm{OT}$

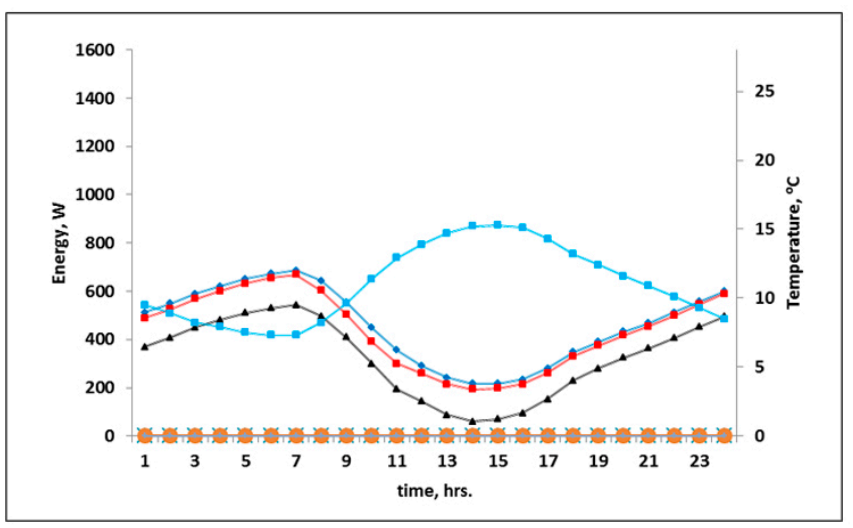

$40 \%$, WWR

\section{Spring}
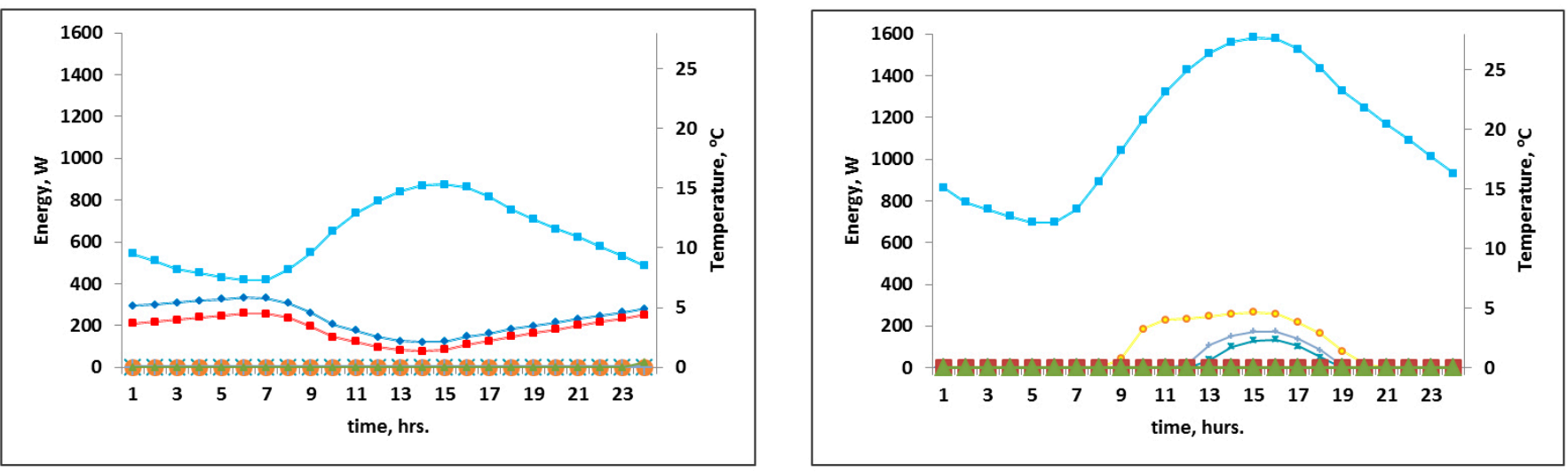

Figure 6. Cont. 
Summer
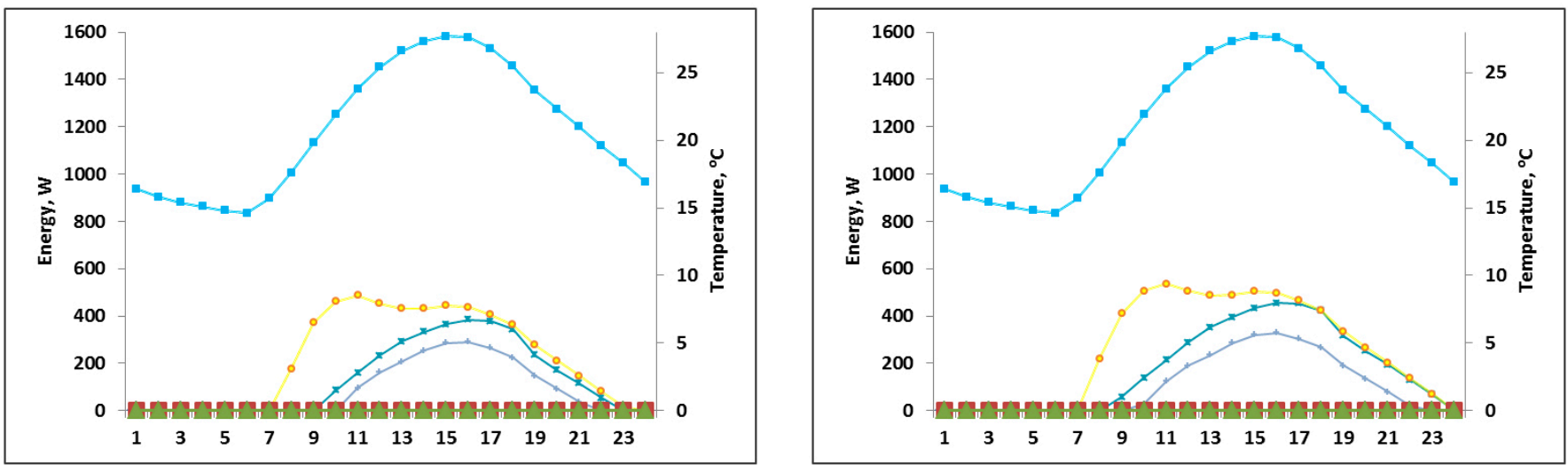

Autumn
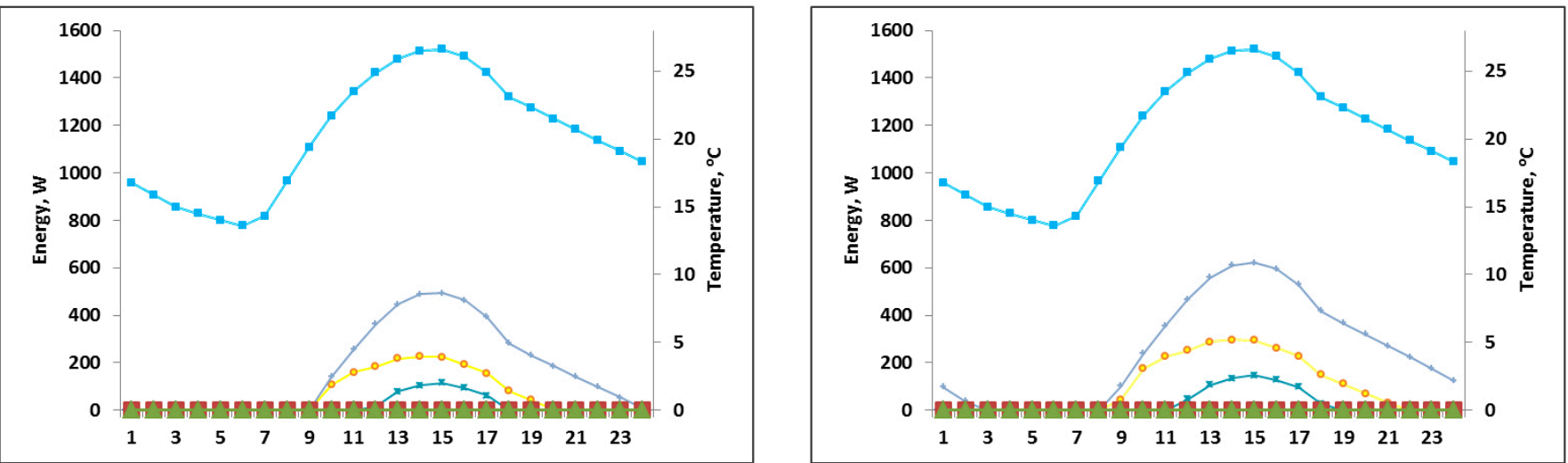

Heating and Cooling of Riyadh City

$10 \%$, WWR

Winter

$40 \%$, WWR

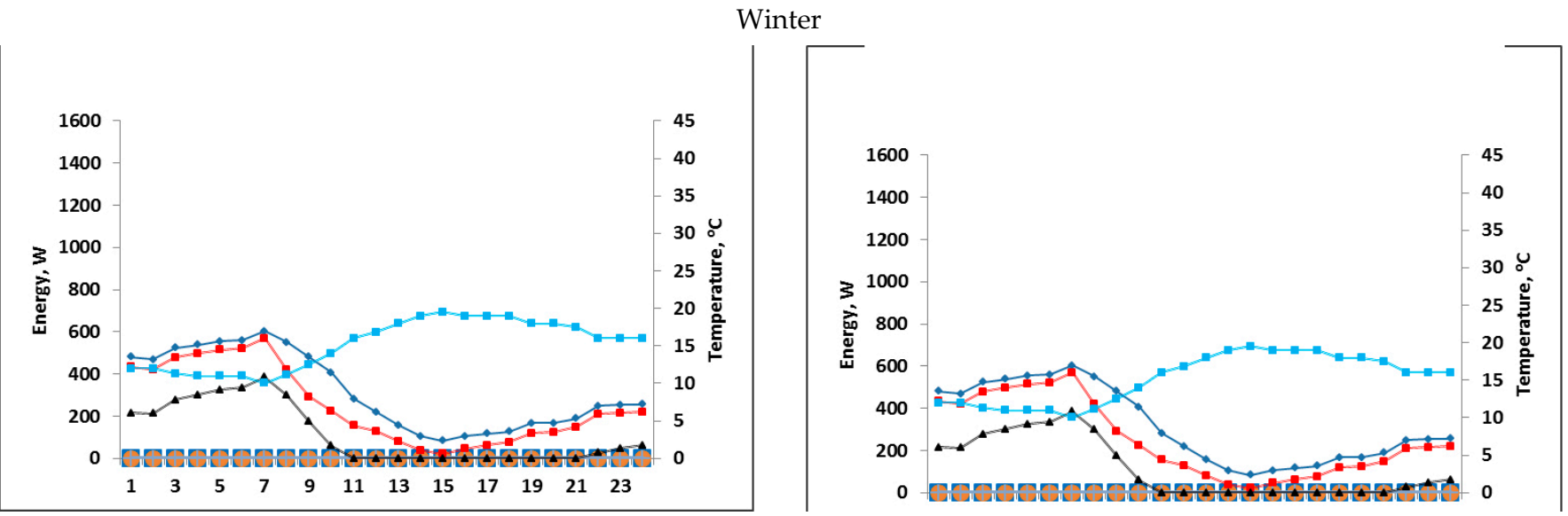

Figure 6. Cont. 
Spring
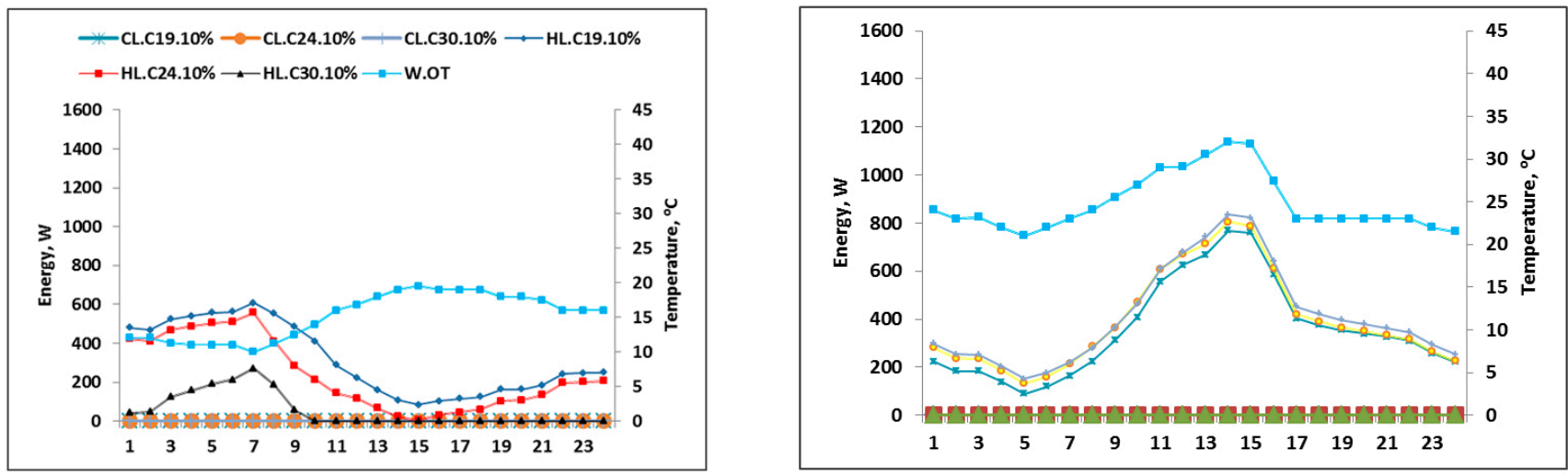

Summer
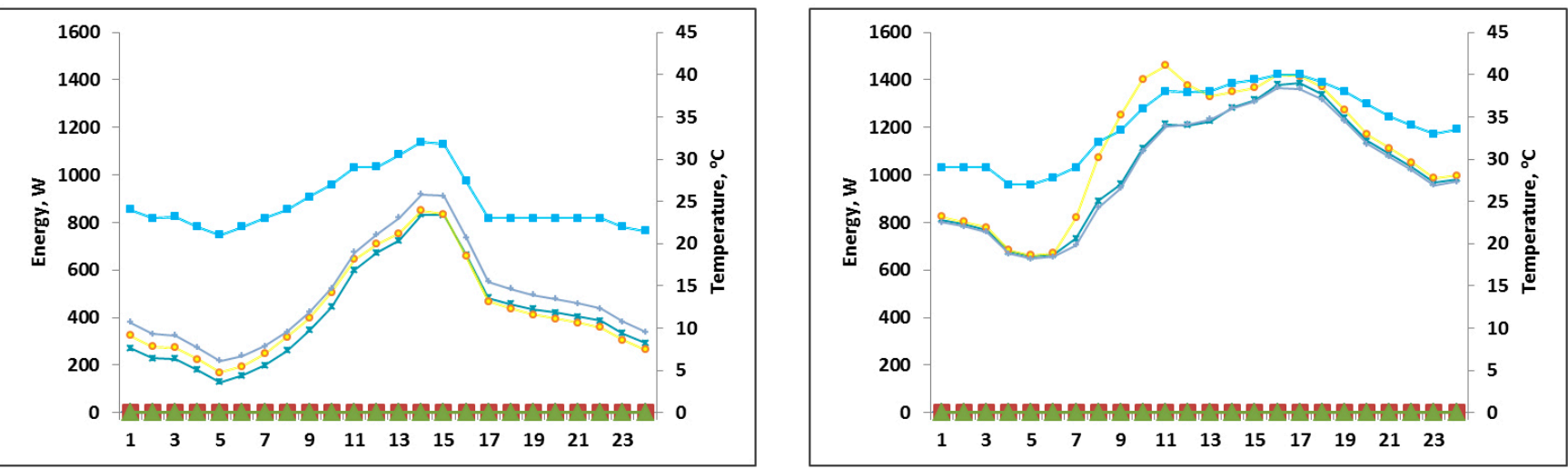

Autumn
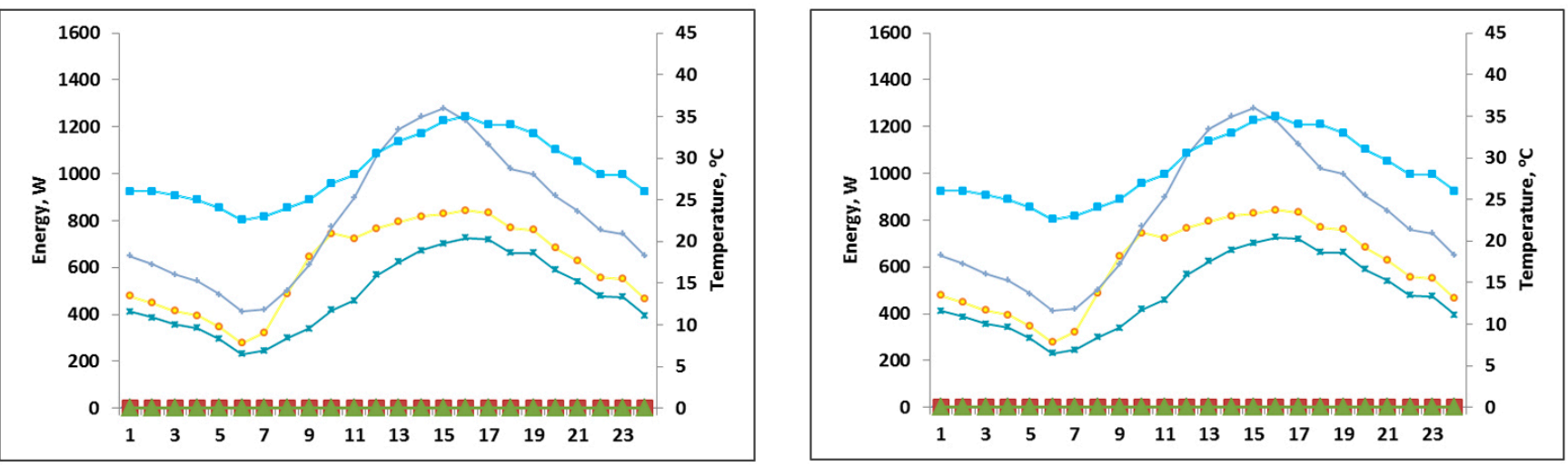

Figure 6. Energy loads of different classrooms within the schools' selected classrooms in different orientations and seasons with a $10 \%$ and $40 \%$ WWR in both Abha and Riyadh.

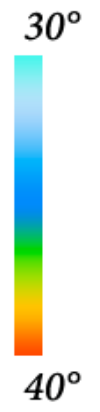

Abha

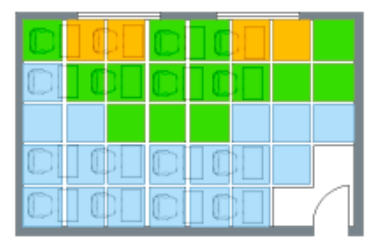

Moderate climate high land
Riyadh

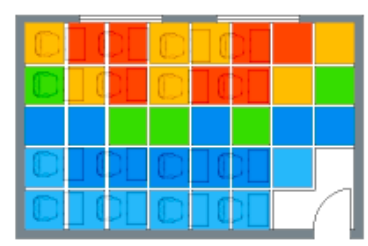

Hot and dry climate

Figure 7. Globe thermometer distribution during the visits to the selected schools. Both classrooms face east. 
Additionally, the findings will contribute to the knowledge behind implementing such systems in any climatic regions, including those investigated. Considering the unified design of schools in Saudi Arabia, known as the prototype school building design (PSBD), the findings will aid in improving the quality of this design and the material selection for use in future schools. Unlike the previous studies, the current research explores the influence of the windows' orientation, as explained in Figures 8 and 9. WWR is not the only element that can contribute to the energy performance in buildings. There are many others as well, such as the U-values of the glazing system. Since windows are a major contributor to building heat transfer, it is recommended to determine the type of glazing precisely. Various U-values were tested in the same condition, and it was found that the modification of the U-value of glazing can have a significant impact on solar heat gain and thus, the total energy consumption in buildings, which can be doubled (Figure 8). It was observed that the type of glazing can double the amount of heat transfer into the indoor built environment, which will have a considerable impact on the indoor temperature as well as the thermal comfort of the students. As classroom C_24 is facing east and is relatively larger than the others, it was noticed that it has a larger amount of solar heat gain compared to the others. Table 2 shows recommended maximum WWR in each climatic zone and orientation, which is based on findings obtained from Tables 3 and 4 .

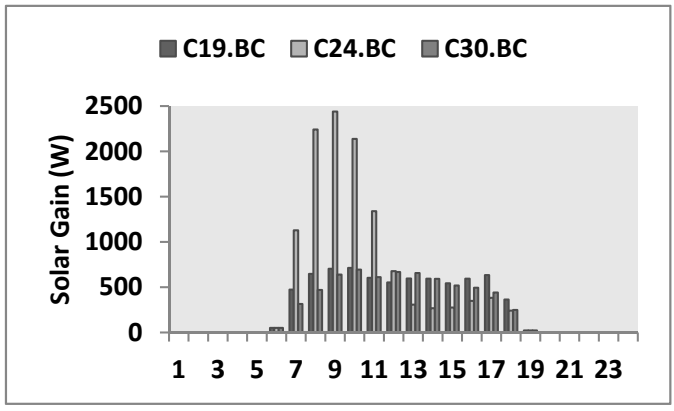

(a)

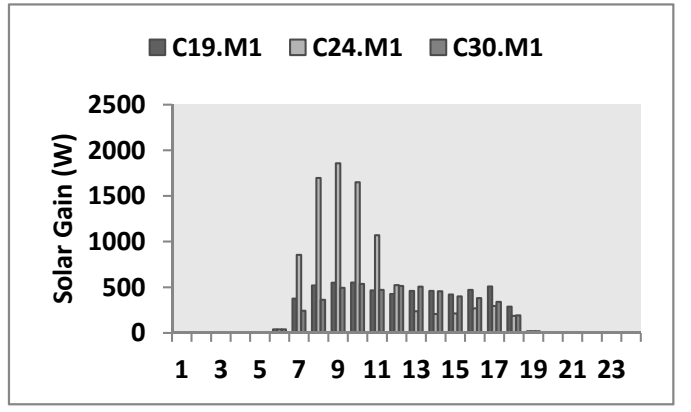

(b)

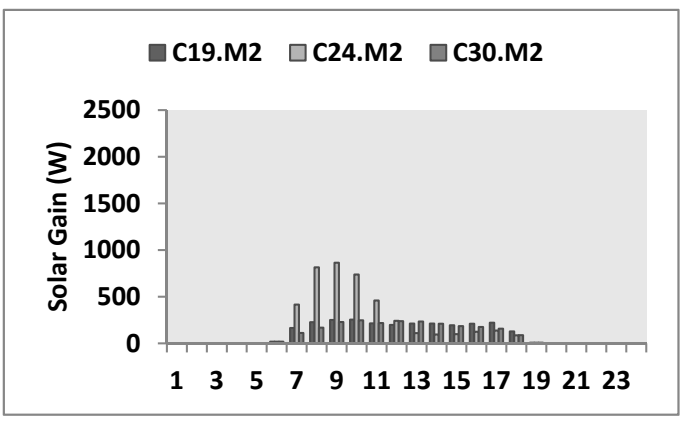

(c)

Figure 8. Significance of the different $U$-values for the same size of window in various orientations where (a) is the base case model, while (b) and (c) are the improved glazing where BC is the base case scenario, M1 is the first improved $\mathrm{U}$-value $\mathrm{W} / \mathrm{m}^{2} . \mathrm{K}$ and $\mathrm{M} 2$ is the second improved U-Value $\mathrm{W} / \mathrm{m}^{2} \cdot \mathrm{K}$. 


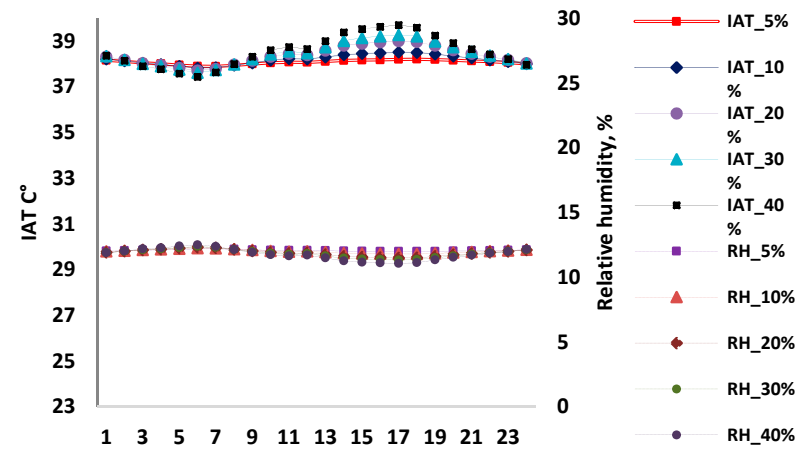

(a)

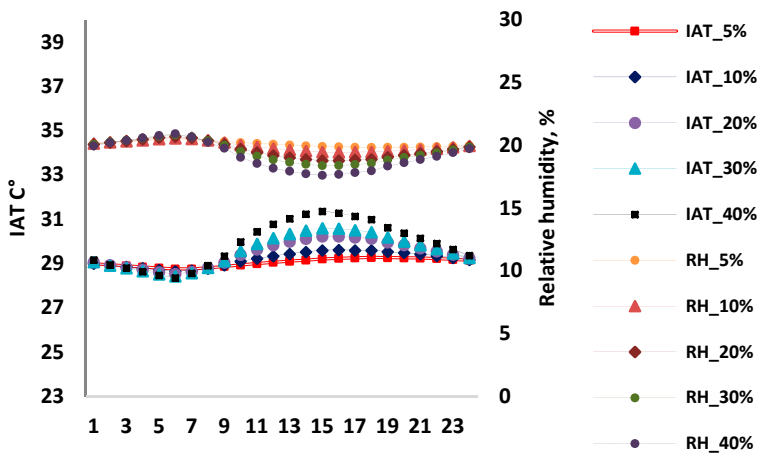

(c)

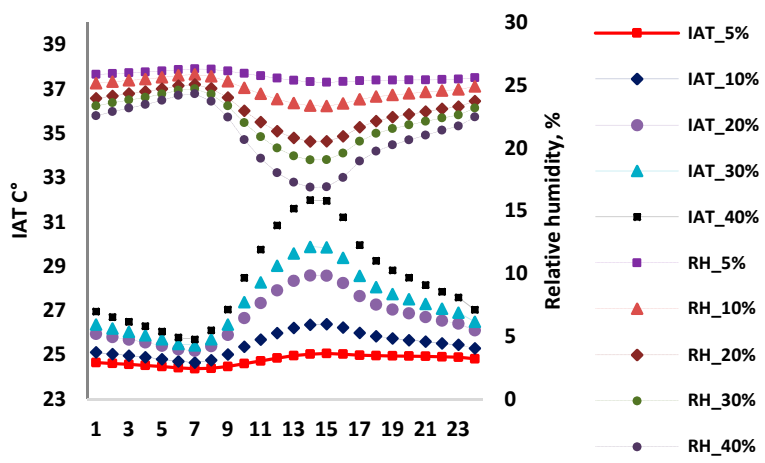

(b)

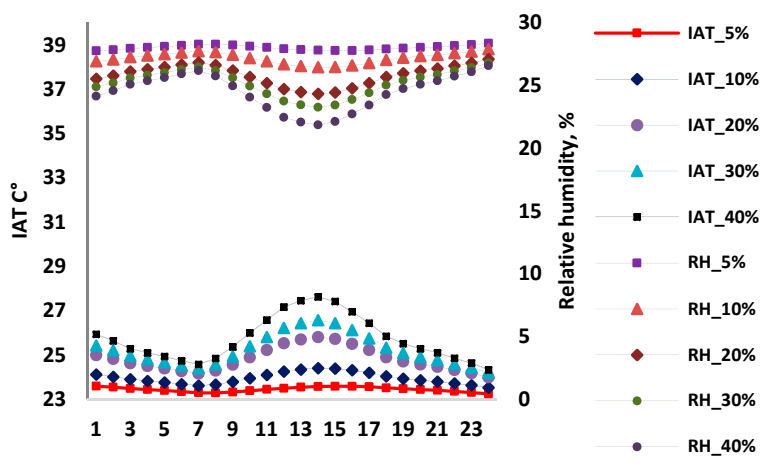

(d)

Figure 9. Parametric studies of various WWR in relation to indoor air temperature (IAT) and relative humidity (RH), where: (a) is the IAT and the RH of C30 in summer for the south-facing classroom in Riyadh, (b) is the IAT and the RH of C30 in winter for the south-facing classroom in Riyadh, (c) is the IAT and RH of C30 in summer for the south-facing classroom in Abha and (d) is the IAT and the RH of C30 in winter for the south-facing classroom in Abha.

Table 2. Recommended maximum WWR in each climatic zone and orientation.

\begin{tabular}{ccc}
\hline & Highland Regions (Abha) & $\begin{array}{c}\text { Hot and Dry Regions } \\
\text { (Riyadh) }\end{array}$ \\
\hline Max WWR in north-facing & $40 \%$ & $30 \%$ \\
Max WWR in east-facing & $35 \%$ & $25 \%$ \\
Max WWR in south-facing & $35 \%$ & $25 \%$ \\
\hline
\end{tabular}

Table 3. Characteristics from testing the various types of glazing.

\begin{tabular}{|c|c|c|c|}
\hline & Materials & Thickness & $\begin{array}{c}\text { Total U-Value } \\
\mathrm{W} / \mathrm{m}^{2} . \mathrm{K}\end{array}$ \\
\hline Base Case Model & Glazing & $10 \mathrm{~mm}$ & 5.55 \\
\hline \multirow{4}{*}{ Model 1} & Glazing & $6 \mathrm{~mm}$ & \multirow{4}{*}{3.95} \\
\hline & Cavity & $12 \mathrm{~mm}$ & \\
\hline & Opt Float & $6 \mathrm{~mm}$ & \\
\hline & Cavity & $12 \mathrm{~mm}$ & \\
\hline \multirow{5}{*}{ Model 2} & Glazing & $6 \mathrm{~mm}$ & \multirow{5}{*}{2.54} \\
\hline & Cavity & $12 \mathrm{~mm}$ & \\
\hline & Opt float & $6 \mathrm{~mm}$ & \\
\hline & Cavity & $12 \mathrm{~mm}$ & \\
\hline & Opt float & $6 \mathrm{~mm}$ & \\
\hline
\end{tabular}


Table 4. Daylight factors in the examined classrooms in winter and summer at $12 \mathrm{pm}$, based on Riyadh's climate.

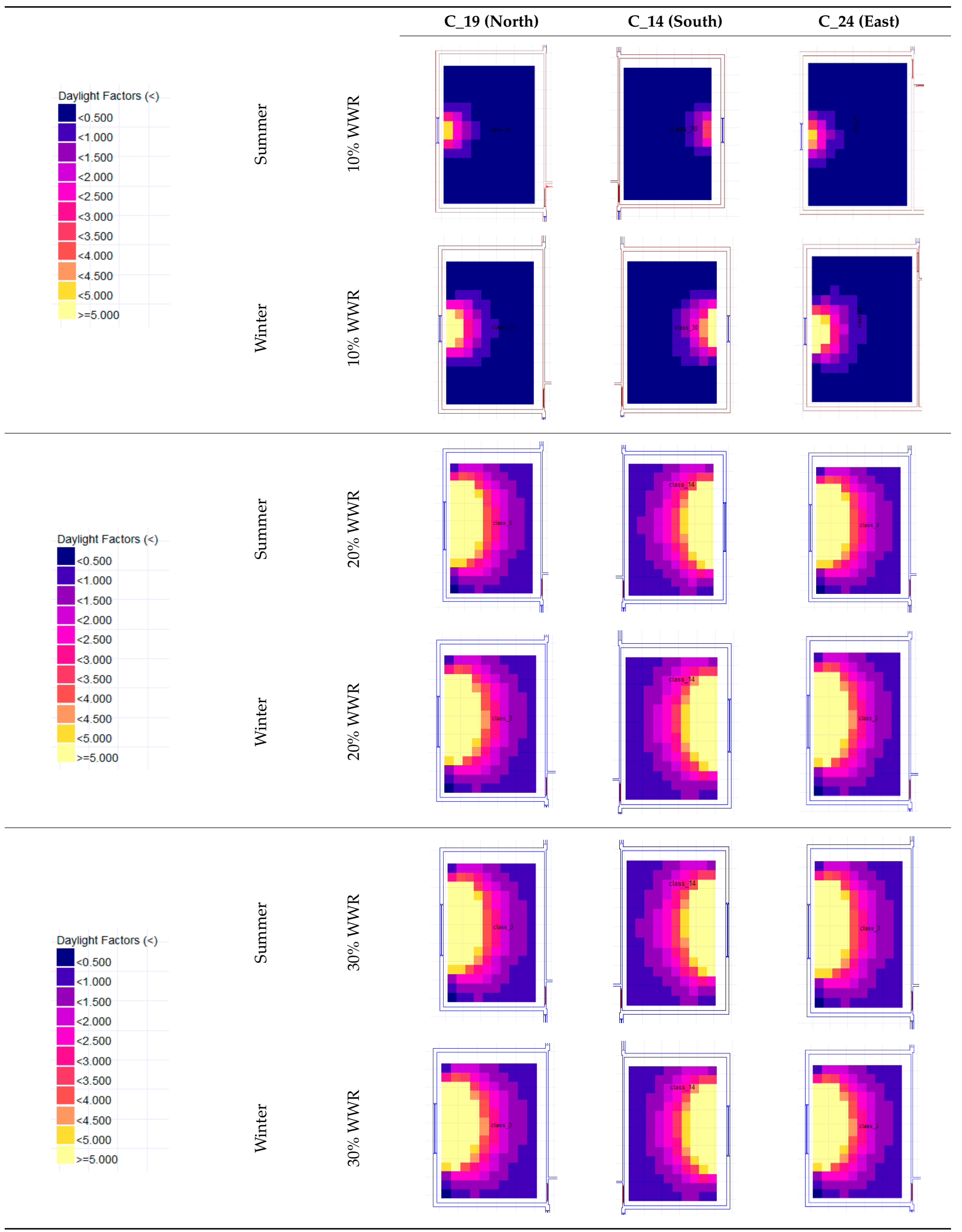


Table 4. Cont

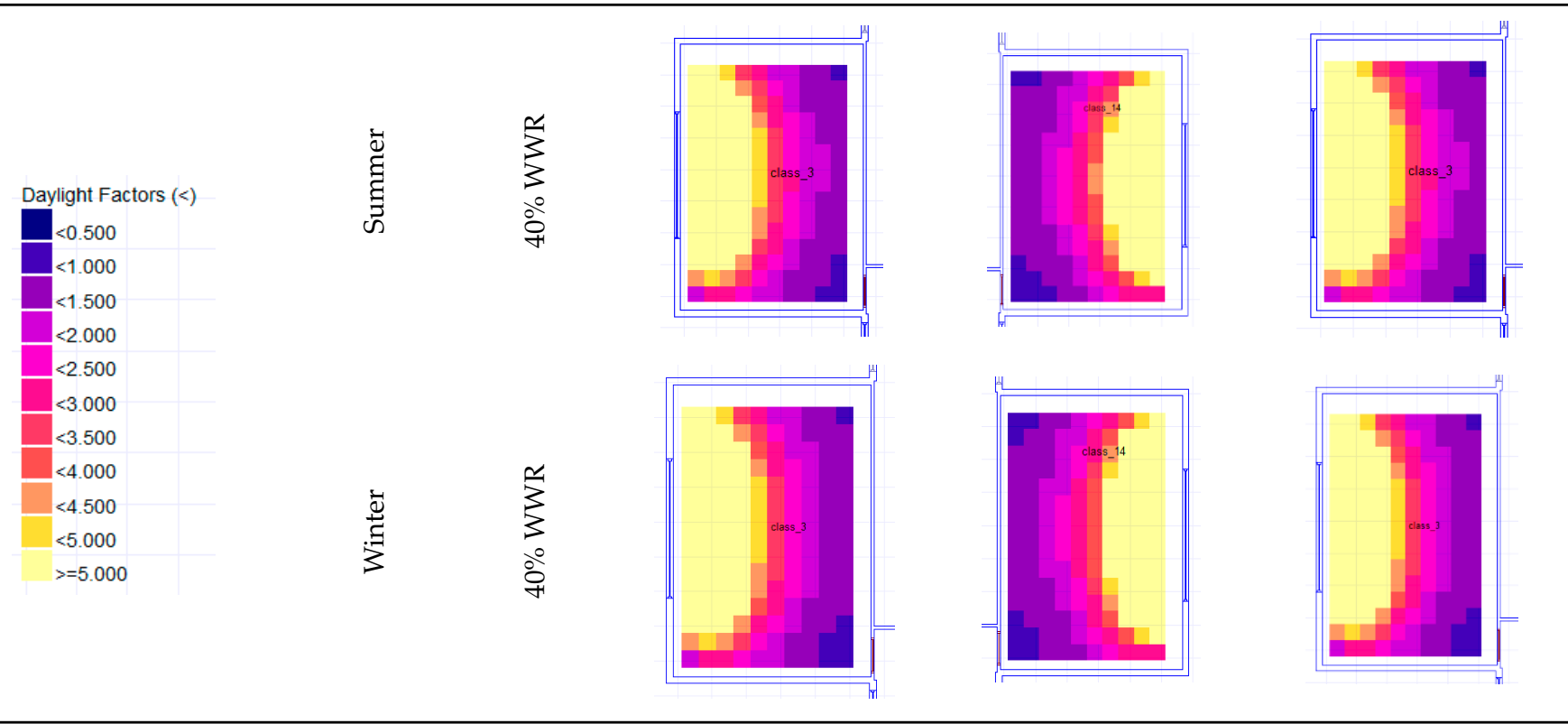

The work of Alwetaishi [7] suggests a WWR of $20 \%$ to $35 \%$. However, this study focused only on energy consumption and it was not clear how this might affect daylight. According to the CIBSE Guide [26], the daylight factor should be between 2\% and 5\% to provide a suitable amount of natural light indoors based on the type of indoor environment. There is a link between the type of building, daylight, and comfort [27]. Based on the CIBSE Guide, all residential rooms should not have a daylight factor higher than $2 \%$, especially in any bedrooms. However, in classrooms, natural light is required if there is no associated glare, which may cause discomfort. The level of daylight presented in Table 4 shows the amount of daylight considering 10\%,20\%,30\%, and 40\% WWR in various orientations in the city of Riyadh. It is clear that the $10 \%$ WWR is not sufficient enough to hold activities in the classrooms such as reading. As a result, a WWR ranging from $30 \%$ to $35 \%$ might be appropriate depending on the orientation in order to provide the ultimate daylight factor combined with optimal building energy efficiency. In addition, the findings of Table 4 highlight that in such a hot region, if the WWR exceeds $20 \%$, it will add only an extra cooling load and the daylight factor will not be affected significantly. As a result, it is not recommended to raise the WWR by more than $20 \%$ except in the case of the north orientation to obtain a larger view of the outdoors. These findings support the work of Alwetaishi [4] who suggested that the WWR should not exceed 10\% in all directions in the city of Riyadh. However, the work of Alwetaishi did not consider the daylight factor. This study, which has combined the aforementioned with the analysis of daylight, proposes that the WWR should be at least $20 \%$ to provide sufficient daylight for the indoor environment socially in buildings such as schools were daytime activities are required.

Based on the findings of this research (Figure 9) including indoor air temperature, the daylight factor, and energy consumption, it can be mentioned that the maximum WWR in higher altitude locations located in hot regions can be $40 \%, 35 \%$, and $35 \%$ in the north, east, and south while in hot dry locations, it is recommended to be $30 \%, 20 \%$, and $20 \%$ in the same sequence of orientations.

\section{Conclusions}

The influence of WWR in a school building was examined under the condition of two different climatic zones in Saudi Arabia, which were hot dry and moderate (high land location). The study used site observations such as the clothing level of the students as well as measurements through the use of a globe thermometer to study the impact of glazing in 
both locations. In addition, an energy computer simulation was used to analyze various thermal aspects such as the indoor temperature and solar heat gain. Moreover, the study used the daylight plug-in to study the influence of daylight distribution considering the current size of the windows. Although the prototype school building design remains the same in both cities, it was found that the design should be modified at least at the level of the windows with respect of the placement area and material used. In the moderate climate, it was found that a larger WWR is more beneficial in the winter in the south, east, and west facing zones but not on the side of the north, which received a lesser amount of direct solar radiation. This is to encourage the greater exploitation of passive solar heating. The $40 \%$ WWR in such a climate aids the zero-heating load in winter, while there was a clear demand for a heating load in the scenario of $10 \%$. The impact of such variation in the WWR between summer and winter for this location was negligible which makes it clear that the larger area for the WWR in a moderate climate is more beneficial considering the variation of each orientation. In a hot and arid climate, the status is different. In Riyadh city, there is a significant and clear heating load in winter and cooling in summer due to the harsh climate. However, the cooling load is more dominant regarding its duration and associated values. Thus, it is more advantageous to have a smaller WWR in most of its zones. This finding is compatible with the research conducted in Riyadh city considering the influence of WWR on the indoor environment [4]. Based on the findings of this research, it can be mentioned that the maximum WWR in moderate and highland locations can be $40 \%, 35 \%$, and $35 \%$ in the north, east, and south while in hot dry locations, it is recommended to be $30 \%, 25 \%$, and $25 \%$ in the same sequence of orientations. In addition to that, for the ultimate results concerning energy consumption and the daylight factor, the WWR should be in the range of $30 \%$ to $35 \%$, and this percentage can be higher in high altitude mountains where the outdoor temperatures are less intense.

Author Contributions: M.A.: Conceptualization, data curation, writing-original draft, investigation, software, validation; O.B.: review and editing, analysis, and the research method. All authors have read and agreed to the published version of the manuscript.

Funding: This research was funded by [Taif University, Researchers Supporting Project] grant number [TURSP-2020/196].

Informed Consent Statement: Informed consent was obtained from all subjects involved in the study.

Acknowledgments: The author would like to acknowledge the finical support provided from Taif University Researchers Supporting Project Number (TURSP-2020/196).

Conflicts of Interest: The author declares no conflict of interest.

\section{References}

1. Chiesa, G.; Acquaviva, A.; Grosso, M.; Bottaccioli, L.; Floridia, M.; Pristeri, E.; Sanna, E.M. Parametric Optimization of Windowto-Wall Ratio for Passive Buildings Adopting A Scripting Methodology to Dynamic-Energy Simulation. Sustainability 2019, 11, 3078. [CrossRef]

2. $\mathrm{Su}, \mathrm{X}$.; Zhang, $\mathrm{X}$. Environmental performance optimization of window-wall ratio for different window type in hot summer and cold winter zone in China based on life cycle assessment. Energy Build. 2010, 42, 198-202. [CrossRef]

3. Bouchlaghem, N. Optimising the design of building envelopes for thermal performance. Autom. Constr. 2000, 10, 101-112. [CrossRef]

4. Alwetaishi, M. Impact of glazing to wall ratio in various climatic regions: A case study. J. King Saud. Univ. Eng. Sci. 2019, 31, 6-18. [CrossRef]

5. Ben-Nakhi, A.E. Minimizing thermal bridging through window systems in buildings of hot regions. Appl. Therm. Eng. 2002, 22, 989-998. [CrossRef]

6. Kamal, A.; Greig, M.; Alhomid, N.; Al-Jafari, A. Kinetics of Human Acetylcholinesterase Inhibition by the Novel Experimental Alzheimer Therapeutic Agent, Tolserine. J. Biochem. Pharmacol. 2000, 60, 561-570. [CrossRef]

7. Alwetaishi, M.; Taki, A. Investigation into energy performance of a school building in a hot climate: Optimum of window-to-wall ratio. Indoor Built Environ. 2020, 29, 24-39. [CrossRef]

8. Gasparella, A.; Pernigotto, G.; Cappelletti, F.; Romagnoni, P.; Baggio, P. Analysis and modelling of window and glazing systems energy performance for a well insulated residential building. Energy Build. 2011, 43, 1030-1037. [CrossRef] 
9. Lee, J.W.; Jung, H.J.; Park, J.Y.; Lee, J.B.; Yoon, Y. Optimization of building window system in Asian regions by analyzing solar heat gain and daylighting elements. Renew. Energy 2013, 50, 522-531. [CrossRef]

10. Khakian, R.; Karimimoshaver, M.; Aram, F.; Benis, S.Z. Modeling Nearly Zero Energy Buildings for Sustainable Development in Rural Areas. Energies 2020, 13, 2593. [CrossRef]

11. Li, J.; Zheng, B.; Chen, X.; Zhou, Y.; Rao, J.; Bedra, K.B. Research on Annual Thermal Environment of Non-Hvac Building Regulated by Window-to-Wall Ratio in a Chinese City (Chenzhou). Sustainanability 2020, 12, 6637. [CrossRef]

12. Detsi, M.; Manolitsis, A.; Atsonios, I.; Mandilaras, I.; Founti, M. Energy savings in an office building with high WWR using glazing systems combining thermochromic and electrochromic layers. Energies 2020, 13, 3020. [CrossRef]

13. Maps of the World: Maps of Saudi Arabia, (n.d.). Available online: http://www.maps-of-the-world.net/maps-of-asia/maps-ofsaudi-arabia/ (accessed on 23 November 2020).

14. Cesari, S.; Valdiserri, P.; Coccagna, M. The Energy Saving Potential of Wide Windows in Hospital Patient Rooms, Optimizing the Type of Glazing and Lighting Control Strategy under Di ff erent Climatic Conditions. Energies 2016, 13, 2116. [CrossRef]

15. Khoukhi, M.; Darsaleh, A.F.; Ali, S. sustainability Retrofitting an Existing O ffi ce Building in the UAE Towards Achieving Low-Energy Building. Sustainability 2020, 12, 2573. [CrossRef]

16. Somasundaram, S.; Thangavelu, S.R.; Chong, A. Effect of Existing Façade's Construction and Orientation on the Performance of Low-E-Based Retrofit Double Glazing in Tropical Climate. Energies 2016, 13, 2016. [CrossRef]

17. Fasiuddin, M. HVAC System Operation Strategies for Energy Conservation and Thermal Comfort in Commercial Buildings in Saudi Arabia. Master's Thesis, King Fahd University of Petroleum and Minerals, Dhahran, Saudi Arabia, 2005.

18. Priyadarsini, R.; Hien, W.N.; David, C.K.W. Microclimatic modeling of the urban thermal environment of Singapore to mitigate urban heat island. Sol. Energy 2008, 82, 727-745. [CrossRef]

19. Berger, T.; Amann, C.; Formayer, H.; Korjenic, A.; Pospichal, B.; Neururer, C.; Smutny, R. Impacts of external insulation and reduced internal heat loads upon energy demand of offices in the context of climate change in Vienna, Austria. J. Build. Eng. 2016, 5, 86-95. [CrossRef]

20. Resuli, P.; Dervishi, S. Thermal performance of cultural heritage Italian housing in Albania. Energy Procedia 2015, 78, 753-758. [CrossRef]

21. Pino, A.; Bustamante, W.; Escobar, R.; Pino, F.E. Thermal and lighting behavior of office buildings in Santiago of Chile. Energy Build. 2012, 47, 441-449. [CrossRef]

22. Dudkiewicz, E.; Fidorów-Kaprawy, N. The energy analysis of a hybrid hot tap water preparation system based on renewable and waste sources. Energy 2017, 127, 198-208. [CrossRef]

23. Kang, D.; Strand, R.K. Analysis of the system response of a spray passive downdraft evaporative cooling system. Build. Environ. 2019, 157, 101-111. [CrossRef]

24. Alwetaishi, M. Can we learn from heritage buildings to achieve nearly zero energy building and thermal comfort? A case study in a hot climate. Adv. Build. Energy Res. 2020, 1-17. [CrossRef]

25. Alwetaishi, M.; Kamel, M.; Al-Bustami, N. Sustainable applications of asphalt mixes with reclaimed asphalt pavement (RAP) materials: Innovative and new building brick. Int. J. Low-Carbon Technol. 2019, 14, 364-374. [CrossRef]

26. CIBSE. Environmental Design A; Page Bros: Norwich, UK, 2006. [CrossRef]

27. Alwetaishi, M.S. Impact of building function on thermal comfort: A review paper. Am. J. Eng. Appl. Sci. 2016, 9, 928-945. [CrossRef] 